\title{
KAJIAN AWAL SUMBER DAYA BATUBARA DAN NISBAH PENGUPASAN (STRIPPING RATIO), DI PULAU NIAS - PROVINSI SUMATERA UTARA
}

\author{
Oleh : \\ Robert Lumban Tobing \\ Kelompok Program Penelitian Energi Fosil, Pusat Sumber Daya Geologi
}

\section{SARI}

Pulau Nias terletak di Samudera Hindia dan berada di bagian Baratdaya Propinsi Sumatera Utara. Daerah ini memiliki sumber daya batubara yang terkandung dalam Formasi Lelematua berumur Miosen Awal Pliosen Bawah dan dalam Formasi Gomo yang berumur Miosen Tengah Pliosen Bawah. Singkapan batubara dari kedua formasi ditemukan masing-masing di Blok Alooa dan Blok Muzoi.

Berdasarkan perhitungan sumber daya batubara daerah kajian, sumber daya batubara Formasi Lelematua pada kedalaman 0-100 meter adalah sebesar 950.671 ton dengan nisbah pengupasan berkisar 28 40, sedangkan pada kedalaman 100 500 meter teridentifikasi sumber daya batubara sebesar 3.870 .351 ton.

Pada Formasi Gomo besar/jumlah sumber daya batubara pada kedalaman 0100 meter adalah 8.707 .353 ton dengan nisbah pengupasan berkisar 21 95, sementara pada kedalaman 100500 meter teridentifikasi sumber daya batubara sebesar 26.920.070 ton.

Kata Kunci : Batubara, Sumber daya, Nisbah Pengupasan

\section{ABSTRACT}

Nias Island is located at Indian Ocean and situated in North Sumatera Province. There are coal resources within the Lelematua Formation of Early Miocene Early Pliocene and Gomo Formation of Middle Miocene Late Pliocene. Both outcrops was discovered respectively at Alooa Block and Muzoi Block.

Based on calculation of coal resources that the coal within Lelematua Formation is included in an hypothetic category with a total amount of 950,671 tonnes on a stripping ratio of about 28 40, at depths of 0-100 meters. While at depths of 100-500 meters, it has an hypotetic coal resource of about 3,870,351 tonnes.

Calculation of coal resources within Gomo Formation identifies an hypotetic resource of about 3,707,353 tonnes at depths of 0-100 meters, on stripping ratio of about 21 95. While at depths of 100 500 meters, it has coal resource of approximately 26,920,070 tonnes.

Keywords : Coal, Resources, Stripping Ratio(SR)

\section{PENDAHULUAN}

Seiring dengan semakin tingginya harga minyak dan gas bumi di pasaran dunia, berbagai kalangan industri mulai beralih menggunakan batubara sebagai sumber energi, misalnya PLTU, industri semen dan industri tekstil. Dengan mempertimbangkan tingginya konsumsi akan komoditi tersebut, maka sudah selayaknya dilakukan kajian-kajian sumber daya batubara di berbagai daerah /cekungan batubara di Indonesia, mengingat nilai keekonomiannya yang semakin kompetitif pada saat ini.

Berdasarkan studi literatur yang mengacu pada Peta Geologi Lembar Nias-Sumatera (Djamal dkk.,1994), Pulau Nias memiliki sumber daya batubara yang signifikan sehingga layak untuk dijadikan obyek kajian. Secara administratif pemerintahan, Pulau Nias termasuk dalam Kabupaten Tapanuli Tengah, Provinsi Sumatera Utara. Daerah kajian dapat di capai dengan penerbangan melalui ibu kota provinsi tersebut atau dengan kendaraan laut melalui pelabuhan Sibolga.

Maksud tulisan ini adalah untuk menyajikan besarnya sumber daya batubara pada kedalaman 0500 meter di bawah permukaan dan besarnya nisbah pengupasan pada lapisan batubara Formasi Lelematua dan Formasi Gomo Pulau Nias. Sementara itu, tujuan utama kajian ini adalah untuk mengetahui besarnya sumberdaya batubara pada kedalaman 0100 meter dan nisbah pengupasan untuk penambangan terbuka, serta besarnya sumber daya batubara pada kedalaman 100500 meter bila akan diusahakan untuk teknik penambangan bawah tanah.

Menurut Fatimah (2006), ketebalan lapisan batubara yang layak ditambang dengan teknik penambangan bawah tanah berkisar antara 2 dan 4 meter. Batubara dengan ketebalan kurang dari 2 meter belum layak dikembangkan untuk saat ini ditinjau dari segi ekonominya. Sedangkan 
batubara dengan ketebalan lebih dari 4 meter masih sulit dilakukan disebabkan oleh sifat fisik batubara yang memperlihatkan banyak kekar dan mudah patah/hancur sehingga dikhawatirkan terjadi runtuhan pada saat penambangan. Dengan pertimbangan tersebut, penyanggaan yang digunakan saat ini hanya diperuntukkan pada lapisan batubara dengan ketebalan 24 meter.

Kemiringan lapisan batubara untuk penambangan terbuka umumnya tidak mempunyai batasan tetapi tergantung pada nisbah pengupasan (stripping ratio) lapisan tanah penutup (overburden). Untuk saat ini, nilai nisbah pengupasan yang disarankan berkisar 7 10 untuk batubara uap dan untuk batubara metalurgi berkisar 12 15 (NEDO, 2003). Sedangkan untuk tambang bawah tanah kemiringan lapisan yang ideal adalah $12^{\circ}$ sampai $20^{\circ}$ (Fatimah, 2006). Hal ini dikaitkan dengan kemampuan peralatan operasional didalam tambang, kemampuan alat mangangkut batubara menuju permukaan (stock pile), serta pertimbangan terhadap keamanan tambang.

Namun untuk kepentingan kajian ini, penulis tidak membatasi ketebalan dan kemiringan lapisan batubara dengan asumsi bahwa nilai ekonomis endapan batubara untuk ditambang tergantung kepada teknologi pada saat itu.

\section{METODOLOGI}

Metodologi kajian meliputi pengamatan terhadap singkapan-singkapan, pemerian, pengukuran ketebalan, pengukuran arah jurus dan kemiringan serta pengambilan conto batubara. Data-data singkapan yang di dapat akan diplot ke peta dasar/ topografi skala 1:50.000.

Sumber daya batubara dihitung berdasarkan data singkapan yang dapat diukur. Penghitungan sumberdaya batubara mengacu pada Klasifikasi Sumber Daya dan Cadangan Batubara Standar Nasional Indonesia (SNI) Amandemen I SNI No. 13-5014-1998, Badan Standarisasi Nasional-BSN.

Perhitungan sumber daya batubara daerah kajian dibagi dalam 2 (dua) Blok yaitu Blok Alooa (Formasi Lelematua) dan Blok Muzoi (Formasi Gomo). Dalam perhitungan sumberdaya batubara dibatasi oleh:

$\square$ Penyebaran ke arah jurus (panjang) satu lapisan berdasarkan singkapan yang dapat dikorelasikan sejauh 1.000 meter dari singkapan terakhir.

$\square$ Penyebaran ke arah kemiringan (lebar) lapisan dibatasi sampai kedalaman 500 meter dihitung tegaklurus dari permukaan singkapan, sehingga lebar singkapan adalah :

$\mathrm{L}=500 / \sin$, dimana adalah sudut kemiringan lapisan batubara.

$\square$ Tebal lapisan adalah tebal rata-rata batubara yang termasuk dalam lapisan tersebut .
Berat Jenis adalah berat Jenis rata-rata yaitu 1,30

Sumber daya batubara dihitung dengan rumus :

Sumber daya $=\{[$ Panjang $(\mathrm{m}) \times$ Lebar $(\mathrm{m}) \times$ Tebal $(\mathrm{m})] \mathrm{x}$ Beratjenis (ton $\left./ \mathrm{m}^{3}\right)$ \}

Perhitungan nisbah pengupasan menggunakan metoda penampang (Gambar 1).

\section{GEOLOGI UMUM}

Menurut Djamal dkk.(1994), stratigrafi umum Pulau Nias diawali dengan terbentuknya batuan dari Kompleks Bancuh berumur OligosenMiosen Awal. Formasi ini tersebar hampir di sepanjang bagian baratlaut daerah kajian. Secara tidak selaras diatas Kompleks Bancuh diendapkan batuan sedimen Formasi Lelematua berumur Miosen Awal-Pliosen Bawah dalam lingkungan sublitoralneritik luar. Penyebaran Formasi Lelematua umumnya berada di bagian tengah Pulau Nias, memanjang pada arah Baratlaut-Tenggara searah dengan daratan Pulau Nias. Pada bagian atas Formasi Lelematua menjemari dengan Formasi Gomo. Penyebaran Formasi Gomo sebagian besar berada di bagian timurlaut Pulau Nias dan memanjang searah baratlaut-tenggara. Bagian atas Formasi Gomo ditindih secara tidak selaras oleh Formasi Gunung Sitoli yang berumur Plio-Plistosen. Sebaran Formasi Gunung Sitoli sebagian besar berada pada sisi terluar Pulau Nias yakni dibagian timurlaut. Litologi Formasi Gunung Sitoli sebagian besar terdiri atas batugamping. Kegiatan selama Holosen lebih didominasi oleh endapan permukaan berupa endapan aluvium yang umumnya berupa endapan rawa dan pantai, terdiri atas bongkahan batugamping, pasir, lumpur dan lempung dengan ketebalan sekitar 2-5 meter (Gambar 2).

Berdasarkan Mandala Geologi Pulau Sumatera (Djamal dkk., 1994), daerah kajian termasuk ke dalam zona akrasi yang membentang arah baratlaut-tenggara. Struktur geologi Pulau Nias berupa lipatan, sesar dan kelurusan dengan arah umum baratlaut-tenggara. Unsur lipatan baik antiklin maupun sinklin sebagian berarah baratlaut dan tenggara. Struktur sesar terdiri atas sesar naik yang sejajar dengan lipatan, kemiringan lipatan ke arah timur sekitar $30^{\circ}$ $40^{\circ}$. Pada beberapa tempat sesar-sesar ini merupakan bidang kontak antara Kompleks Bancuh dengan batuan sedimen yang lebih muda. Sebagian dari sesar naik dan lipatan yang terjadi kemudian terpotong oleh sesar-sesar mendatar dan sesar normal. Kelurusan sesar terjadi pada batuan berumur Tersier yang mempunyai arah baratlaut-tenggara.

Secara umum morfologi Pulau Nias merupakan daerah dataran rendah, perbukitan bergelombang lemah hingga terjal dengan ketinggian mencapai 500 meter diatas permukaan laut. Satuan morfologi dataran rendah di mulai dari garis pantai hingga 5 (lima) km kearah 
perkampungan/daratan. Dataran rendah ini tersusun dari endapan aluvium, endapan pantai dan endapan gamping yang berasal dari Formasi Gunung Sitoli. Morfologi perbukitan bergelombang lemah sampai sedang umumnya tersusun atas batugamping, batupasir dan batulempung yang berasal dari Formasi Gomo. Morfologi perbukitan terjal terdiri atas susunan batuan dari Formasi Lelematua. Arah perbukitan umumnya relatif baratlaut-tenggara atau hampir searah dengan kedudukan Pulau Nias. Pola aliran sungai di daerah timur umumnya sub paralel-paralel, sedangkan pada bagian utara berupa sub dendritik. Tingkat erosi sungai berada pada stadium muda dewasa.

\section{HASIL KAJIAN}

Berdasarkan pengamatan data-data singkapan batubara di lapangan, endapan batubara Pulau Nias terdapat pada Formasi Lelematua dan Formasi Gomo. Pada Formasi Lelematua batubara terdapat sebagai sisipan pada lapisan batulempung. Litologi formasi ini terutama terdiri atas breksi dan konglomerat dengan sisipan batupasir dan batulempung. Breksi umumnya terdiri dari komponen tufaan dengan ukuran antara $0,55 \mathrm{~cm}$, menyudut sampai menyudut tanggung. Sisipan batupasir berwarna abu-abu sampai kekuningan dengan ukuran butir halus, berkomposisi dasitan, mengandung glaukonit, memperlihatkan perlapisan dan mempunyai struktur sedimen paralel laminasi. Dari ditemukannya glaukonit, formasi ini diperkirakan diendapkan dalam lingkungan laut dangkal. Lapisan batubara pada formasi ini terdapat pada Blok Alooa, terdiri atas 2 (dua) lapisan batubara dengan penamaan lapisan $E$ dan

Lapisan E mempunyai sebaran ke arah lateral sekitar 2.700 meter dengan ketebalan rata-rata 0,73 meter. Lapisan ini dikorelasikan berdasarkan singkapan yang diamati pada titik pengamatan N5, N6 dan N7 (Tabel 1) yang tersingkap pada dinding bukit di sekitar Desa Alooa. Batubara pada singkapan-singkapan ini secara megaskopis mempunyai kesamaan batubara berwarna hitam, terang, keras, belahan memanjang-sub konkoidal, agak mudah hancur (Foto 1) dengan arah jurus lapisan rata-rata sekitar $\mathrm{N} 320 \mathrm{oE}$ dengan kemiringan 340-510. Lapisan batubara ini diinterpretasikan sebagai lapisan batubara yang berkembang pada bagian Baratdaya sayap antiklin Alooa.

Lapisan F memiliki kesamaan litologi dan sifat fisik batubara pada lokasi N3, N4 dan N5 (Tabel 1), berwarna hitam, terang, keras, konkoidal, berlapis dengan arah jurus berkisar 136o-141o. Diperkirakan batubara pada lapisan ini merupakan lapisan yang berada pada sayap antiklin Alooa bagian timurlaut. Kontinuitas sebaran ke arah lateral sekitar 2.600 meter dengan tebal lapisan rata-rata 1,09 meter.

Pada Formasi Gomo lapisan batubara diendapkan sebagai sisipan pada lapisan batulempung. Litologi Formasi
Gomo terdiri atas lapisan batulempung dengan sisipan batubara, batupasir, batugamping dan napal tufaan. Sisipan batubara ditemukan di sekitar Sungai Muzoi (Blok Muzoi), terdiri atas 4 (empat) lapisan batubara dengan penamaan Lapisan A, B, C dan D.

Lapisan A diperkirakan mempunyai sebaran lateral berkisar 1.000 meter, ketebalan rata-rata 1,00 meter dengan arah jurus /kemiringan lapisan N170oE/5 o. Lapisan batubara diinterpretasikan berdasarkan singkapan yang diamati pada stasiun pengamatan N12 (Tabel 1) yang tersingkap pada anak Sungai Muzoi. Batubara berwarna coklat kehitam-hitaman, kusam, agak lunak, terdapat struktur kayu (Foto 2).

Lapisan B merupakan lapisan batubara yang berada di bagian bawah dari lapisan A. Sebaran lapisan batubara ke arah lateral berkisar 1.000 meter, ketebalan lapisan batubara berkisar 0,50 meter dengan arah jurus/kemiringan batubara N173oE/07o. Lapisan batubara ini diinterpretasikan berdasarkan singkapan yang diamati pada stasiun pengamatan N11 (Tabel 1). Secara megaskopis batubara berwarna hitam, kusam, belahan memanjang, terdapat struktur kayu dan mengotori tangan (Foto 2).

Lapisan C diamati pada singkapan batubara di lokasi N13 (Tabel 1). Tebal lapisan batubara 1,70 meter dengan arah jurus/kemiringan lapisan $\mathrm{N} 18 \mathrm{oE} / 18$ o. Secara umum ciri batubara mirip dengan batubara pada lapisan A dan B. Batubara berwarna coklat kehitaman, kusam, belahan memanjang, terdapat struktur kayu dan mengotori tangan. Pada bagian baratlaut lapisan ini terpotong oleh struktur sesar.

Lapisan D merupakan korelasi dari singkapan batubara pada lokasi N01, N02, NA01, NA02, N14, N15, N16 (Tabel 1). Setiap singkapan mempunyai arah jurus yang bervariasi antara $\mathrm{N} 150 \mathrm{oEN} 175 \mathrm{oE}$ dengan kemiringan 3o14o. Berdasarkan pengamatan litologi, ketujuh singkapan terdapat kesamaan pada sifat fisik batubara dan lapisan pengapitnya. Pada umumnya batubara berwarna coklat kehitaman, kusam, belahan memanjang dan terdapat struktur kayu. Batubara pada umumnya terdapat sebagai sisipan pada lapisan batulempung berwarna kuning kecoklatan sampai abu-abu tua. Berdasarkan korelasi dari singkapan yang ada, sebaran lapisan D diperkirakan mencapai 5.200 meter dengan tebal lapisan rata-rata 1,18 meter.

\section{PEMBAHASAN}

Berdasarkan kajian peta sebaran batubara, diinterpretasikan bahwa Formasi Lelematua dan Formasi Gomo merupakan formasi pembawa batubara (Gambar 3). Endapan batubara di daerah kajian umumnya berarah tenggarabaratlaut dengan kemiringan berkisar $4^{\circ}-51^{\circ}$ dan ketebalan berkisar $0,51,82$ meter. 
Di bagian Timur pada Blok Alooa batubara terakumulasi pada Formasi Lelematua. Jumlah lapisan batubara pada formasi ini sebanyak 2 (dua) lapisan yaitu lapisan E dan F, sedangkan di bagian barat pada Blok Muzoi batubara terakumulasi pada Formasi Gomo. Jumlah lapisan pada formasi ini sebanyak 4 (empat) lapisan yaitu lapisan A, B, C dan D (Gambar 4)

Dari hasil perhitungan sumber daya batubara (klasifikasi hipotetik) pada Blok Alooa dan Blok Muzoi diperoleh sumberdaya batubara dan nisbah pengupasan sebagai berikut :

\section{Blok Alooa}

Lapisan E, pada kedalaman 0100 meter dari permukaan, jumlah sumber daya batubara sebesar 337.471 ton dengan nisbah pengupasan sebesar $1: 40$ (Tabel 2). Pada kedalaman 100-200 meter sebesar 371.653 ton, kedalaman 200-300 meter sebesar 374.538 ton, kedalaman 300-400 meter sebesar 377.422 ton dan pada kedalaman 400-500 meter sebesar 380.307 ton (Tabel 3).

Lapisan F, Pada kedalaman 0-100 meter dari permukaan, jumlah sumber daya batubara sebesar 613.200 ton dengan nisbah pengupasan $1: 28$. Pada kedalaman 100-200 meter sebesar 608.048 ton, kedalaman 200-300 meter sebesar 597.088 ton, kedalaman 300-400 meter sebesar 586.128 ton dan pada kedalaman 400-500 meter sebesar 575.167 ton.

\section{Blok Muzoi}

Lapisan A, pada kedalaman 0100 meter dari permukaan, jumlah sumber daya batubara sebesar 1.493.695 ton dengan nisbah pengupasan $1: 37$ (Tabel 2). Pada kedalaman 100-200 meter sebesar 1.493.695 ton, kedalaman 200-300 meter sebesar 1.493.695 ton (Tabel3).

- Lapisan B, pada kedalaman 0-100 meter dari permukaan, jumlah sumber daya batubara sebesar 533.000 ton dengan nisbah pengupasan $1: 95$ (Tabel 2)
Pada kedalaman 100-200 meter sebesar 533.000 ton, kedalaman 200-300 meter sebesar 533.000 ton, kedalaman 300-400 meter sebesar 533.000 ton dan kedalaman 400-500 meter sebesar 533.000 ton (Tabel 3).

Lapisan C, pada kedalaman 0-100 meter dari permukaan, jumlah sumber daya batubara sebesar 719.329 ton dengan nisbah pengupasan $1: 21$ (Tabel 2). Pada kedalaman 100-200 meter sebesar 875.499 ton, kedalaman 200-300 meter sebesar 1.037.598 ton, kedalaman 300-400 meter sebesar 1.034.132 ton dan kedalaman 400-500 meter sebesar 1.100.040 ton (Tabel 3).

$\square$ Lapisan D, pada kedalaman 0-100 meter dari permukaan, jumlah sumber daya batubara sebesar 5.961.329 ton dengan nisbah pengupasan $1: 37$ (Tabel 2). Pada kedalaman pada kedalaman 100-200 meter sebesar 5.382.252 ton, kedalaman 200-300 meter sebesar 4.797.100 ton, kedalaman 300-400 meter sebesar 4.172.066 ton dan pada kedalaman 400-500 meter sebesar 3.401.990 ton (Tabel 3).

\section{KESIMPULAN}

Dari hasil kajian sumber daya batubara Blok Alooa dan Blok Muzoi pada kedalaman 0100 meter diperoleh total sumber daya sebesar 9.658.024 ton dengan nisbah pengupasan berkisar 21 95. Sedang pada kedalaman 100-500 meter diperoleh total sumber daya batubara sebesar 30.790.421 ton.

\section{UCAPAN TERIMA KASIH}

Penulis menyampaikan terima kasih yang sebesar-besarnya kepada Ir. Soekardjo, M.Sc, Ir. Asep Suryana, Ir. Deddy Amarullah dan Ir.S.M.Tobing, M.Sc atas dukungan kepada penulis serta kepada Ir.Agus Subarnas yang telah begitu banyak memberikan masukanmasukan kepada penulis sehingga tulisan ini dapat diajukan untuk dipublikasikan, serta kepada semua pihak yang telah membantu tersusunnya tulisan ini.

\section{ACUAN}

Badan Standarisasi Nasional-BSN., 1998. Klasifikasi Sumber Daya-dan Cadangan Batubara Standar Nasional Indonesia (SNI), AmandemenI SNINo. 13-5014-1998.

Djamal,B., Gunawan,W.,Ratman,N.,Simanjuntak,TO.,1994. Peta Geologi Lembar Nias Sumatera, Skala 1 :250.000, Pusat Penelitian dan Pengembangan Geologi.

Fatimah, 2006. Kajian Awal Potensi Batubara Untuk Tambang Bawah Tanah Daerah Bontang dan Sekitarnya Provinsi Kalimantan Timur; Buletin Pusat Sumber Daya Geologi Vol.1,No.3, Halaman 21-29.

NEDO Proyek Alih Teknologi Pertambangan Batubara, 2003. Perencanaan Penambangan, Bahan Pelajaran Pelatihan Umum Teknik Penambangan Batubara.

Pusat Pengembangan Tenaga Pertambangan, 1994. Kursus Perencanaan Tambang.

Tim Inventarisasi Batubara Daerah Marginal Pulau Nias,2006. Laporan Pendahuluan Kegiatan Inventarisasi Batubara Daerah Marginal Pulau Nias, Provinsi Sumatera Utara. 
Tabel 1. Data Singkapan Batubara Daerah Kajian (Robert L.Tobing, dkk., 2006).

\begin{tabular}{|c|c|c|c|c|c|c|}
\hline No & Lokasi & $\begin{array}{c}\text { Jurusl } \\
\text { Kemiringan }\end{array}$ & Koor & BT & Tebal & Litologi \\
\hline 1 & N 01 & $170 / 07$ & 011510.10 & $\begin{array}{l}9728 \\
15.09\end{array}$ & $>1.20$ & $\begin{array}{l}\text { Batubara, coklat } \\
\text { kehitaman,kusam, belahan } \\
\text { memanjang, tdpt str kayu, } \\
\text { mengotori tangan }\end{array}$ \\
\hline 2 & $\mathrm{~N} 02$ & $175 / 8$ & 011500.32 & $\begin{array}{l}9728 \\
21.16\end{array}$ & $>1.00$ & $\begin{array}{l}\text { Batubara, coklat } \\
\text { kehitaman, kusam, tdpt str } \\
\text { kayu,mengotori tangan } \\
\text { Batubara, coklat }\end{array}$ \\
\hline 3 & NA 01 & $160 / 04$ & 011455.03 & $\begin{array}{l}9728 \\
27.23\end{array}$ & $>1.00$ & $\begin{array}{l}\text { kehitaman,kusam, belahan } \\
\text { memanjang, tdpt str kayu, } \\
\text { mengotori tangan } \\
\text { Batubara, coklat }\end{array}$ \\
\hline 4 & NA 02 & $152 / 12$ & 011447.28 & $\begin{array}{l}9728 \\
35.33\end{array}$ & $>0.85$ & $\begin{array}{l}\text { kehitaman,kusam, belahan } \\
\text { memanjang, tdpt str kayu, } \\
\text { mengotori tangan } \\
\text { Batubara, coklat }\end{array}$ \\
\hline 5 & N 16 & $176 / 14$ & 011432.21 & $\begin{array}{l}9728 \\
43.42\end{array}$ & 1.82 & $\begin{array}{l}\text { kehitaman,kusam, belahan } \\
\text { memanjang, tdpt str kayu, } \\
\text { mengotori tangan. Tersingkap di } \\
\text { sungai Muzoi }\end{array}$ \\
\hline 6 & N 15 & $150 / 04$ & 011348.20 & $\begin{array}{l}9729 \\
06.09\end{array}$ & 1.20 & $\begin{array}{l}\text { Batubara, coklat } \\
\text { kehitaman, kusam, tdpt str } \\
\text { kayu,mengotori tangan } \\
\text { Batubara, coklat }\end{array}$ \\
\hline 7 & N 14 & $161 / 43$ & 011332.30 & $\begin{array}{l}9729 \\
19.04\end{array}$ & 1.22 & $\begin{array}{l}\text { kehitaman,kusam, belahan } \\
\text { memanjang, tdpt str kayu, } \\
\text { mengotori tangan. Tersimgkap di } \\
\text { tengah sungai } \\
\text { Batubara, coklat }\end{array}$ \\
\hline 8 & N 13 & $184 / 18$ & 011314.37 & $\begin{array}{l}9729 \\
02.39\end{array}$ & 1.70 & $\begin{array}{l}\text { kehitaman,kusam, belahan } \\
\text { memanjang, tdpt str kayu, } \\
\text { mengotori tangan }\end{array}$ \\
\hline 9 & N 12 & $170 / 05$ & 011222.21 & $\begin{array}{l}9731 \\
16.11\end{array}$ & 1.00 & $\begin{array}{l}\text { Batubara, coklat kehitaman- } \\
\text { hityam, kusam, agak lunak, tdpt } \\
\text { str kayu,mengotori tangan }\end{array}$ \\
\hline 10 & N 11 & $173 / 07$ & 011154.10 & $\begin{array}{l}9730 \\
56.18\end{array}$ & $>0.50$ & $\begin{array}{l}\text { Batubara, hitam, kusam, belahan } \\
\text { memanjang, tdpt str kayu, } \\
\text { mengotori tangan }\end{array}$ \\
\hline 11 & $\mathrm{NO} 03$ & $136 / 15$ & 011751.07 & $\begin{array}{l}9732 \\
33.32\end{array}$ & $>1.30$ & $\begin{array}{l}\text { Batubara, hitam,terang, keras, } \\
\text { konkoidal (Ds Najalau Alooa) }\end{array}$ \\
\hline 12 & N 04 & $129 / 07$ & 011744.55 & $\begin{array}{l}9732 \\
48.29\end{array}$ & 1.11 & $\begin{array}{l}\text { Batubara, hitam,terang, keras, } \\
\text { konkoidal, berlapis }\end{array}$ \\
\hline 13 & N 05 & $141 / 45$ & 011738.08 & $\begin{array}{l}9732 \\
56.39\end{array}$ & $>0.85$ & $\begin{array}{l}\text { Batubara, hitam,terang, keras, } \\
\text { konkoidal, berlapis, }\end{array}$ \\
\hline 14 & N 06 & $320 / 12$ & 011704.20 & $\begin{array}{l}9732 \\
49.51\end{array}$ & $>0.50$ & $\begin{array}{l}\text { Batubara, hitam, agak } \\
\text { kusam,belahan memanjang-sub } \\
\text { Konkoidal, britle }\end{array}$ \\
\hline 15 & N 07 & $320 / 51$ & 011659.31 & $\begin{array}{l}9733 \\
01.24\end{array}$ & $>0.80$ & $\begin{array}{l}\text { Batubara, hitam, agak kusam, } \\
\text { belahan sub Konkoidal, agak } \\
\text { lapuk, }\end{array}$ \\
\hline 16 & N 08 & $321 / 51$ & 011654.02 & $\begin{array}{l}9733 \\
09.34\end{array}$ & $>0.93$ & $\begin{array}{l}\text { Batubara, hitam,terang, keras, } \\
\text { belahan memanjang-sub } \\
\text { konkoidal, agak mudah hancur }\end{array}$ \\
\hline
\end{tabular}


Tabel 2. Sumberdaya Batubara dan Nisbah Pengupasan Pada Kedalaman 0-100 meter (Robert L.Tobing, 2007).

\begin{tabular}{|c|c|c|c|c|c|c|c|}
\hline Blok & $\begin{array}{l}\text { Lapisan } \\
\text { Batubara }\end{array}$ & $\begin{array}{l}\text { Luas } \\
\left(\mathrm{m}^{2}\right)\end{array}$ & $\begin{array}{l}\text { Tebal } \\
(\mathrm{m})\end{array}$ & $\begin{array}{l}\text { Berat } \\
\text { Jenis }\end{array}$ & $\begin{array}{c}\text { Sumberdaya } \\
\text { Batubara } \\
\text { (ton) }\end{array}$ & $\begin{array}{c}\text { Overburden } \\
\qquad\left(\mathrm{m}^{3}\right)\end{array}$ & $\begin{array}{c}\text { Stripping } \\
\text { Ratio }\end{array}$ \\
\hline \multirow[t]{6}{*}{ Muzoi } & & 114899 & & & & & \\
\hline & A & 6 & 1 & 1.3 & 1493695 & 55329898 & 37 \\
\hline & B & 820000 & 0.5 & 1.3 & 533000 & 50653229 & 95 \\
\hline & C & $\begin{array}{l}325488 \\
388613\end{array}$ & 1.7 & 1.3 & 719329 & 15273645 & 21 \\
\hline & D & 4 & 1.18 & 1.3 & 5961329 & 221819491 & 37 \\
\hline & & & & $\begin{array}{c}\text { Total } \\
\text { Sumberdaya }\end{array}$ & 8707353 & 343076263 & \\
\hline \multirow[t]{4}{*}{ Alooa } & - & & & & & & \\
\hline & $E$ & 355607 & 0.73 & 1.3 & 337471 & 13657519 & 40 \\
\hline & $\mathrm{F}$ & 432745 & 1.09 & 1.3 & 613200 & 16926197 & 28 \\
\hline & & & & $\begin{array}{c}\text { Total } \\
\text { Sumberdaya }\end{array}$ & 950671 & 30583716 & \\
\hline
\end{tabular}

Tabel 3. Sumberdaya Batubara Pada Kedalaman 100-500 meter (Robert L.Tobing, 2007)

\begin{tabular}{|c|c|c|c|c|c|}
\hline Blok & Lapisan & \multicolumn{4}{|c|}{ Sumber Daya Hipotetik (ton) } \\
\hline & Batubara & $100 \mathrm{~m}-200 \mathrm{~m}$ & $200 \mathrm{~m}-300 \mathrm{~m}$ & $300 \mathrm{~m}-400 \mathrm{~m}$ & $400 \mathrm{~m}-500 \mathrm{~m}$ \\
\hline Muzoi & $\mathrm{A}$ & 1493695 & 1493695 & - & - \\
\hline & $\mathrm{B}$ & 533000 & 533000 & 533000 & 533000 \\
\hline & $\mathrm{C}$ & 875499 & 1037598 & 1034132 & 1100040 \\
\hline & $\mathrm{D}$ & 5382252 & 4797100 & 4172066 & 3401990 \\
\hline Alooa & Total Sumberdaya & 8284446 & 7861393 & 5739198 & 5035030 \\
\hline & $\mathrm{E}$ & 371653 & 374538 & 377422 & 380307 \\
& $\begin{array}{c}\text { Total } \\
\text { Sumberdaya }\end{array}$ & 608048 & 597088 & 586128 & 575167 \\
& 979701 & 971626 & 963550 & 955474 \\
\hline
\end{tabular}




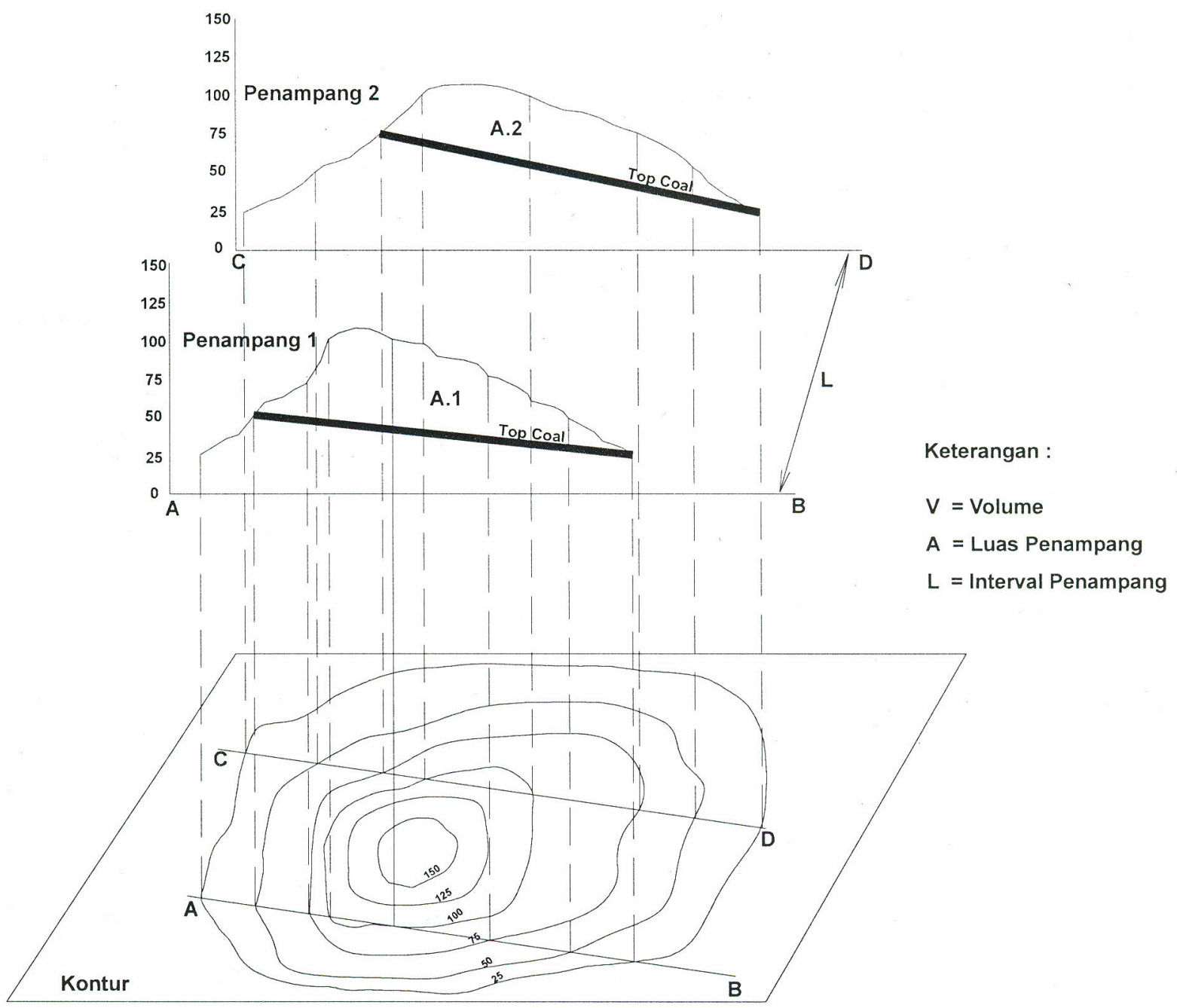

Gambar 1. Pemodelan Penampang Pengukuran Nisbah Pengupasan (Robert L.Tobing, 2007)

I. Rumus End Area

$\mathrm{V}=((\mathrm{A} 1+\mathrm{A} 2) \times \mathrm{L} / 2$

II. Rumus untuk gabungan beberapa penampang

$\mathrm{V}=(\mathrm{A} 1+2 \cdot \mathrm{A} 2+2 \cdot \mathrm{A} 3+\ldots+\mathrm{An}) \times \mathrm{L} / 2$

III. Rumus Baji (Wedge)

$\mathrm{V}=\mathrm{A} / 2 \times \mathrm{L}$ 


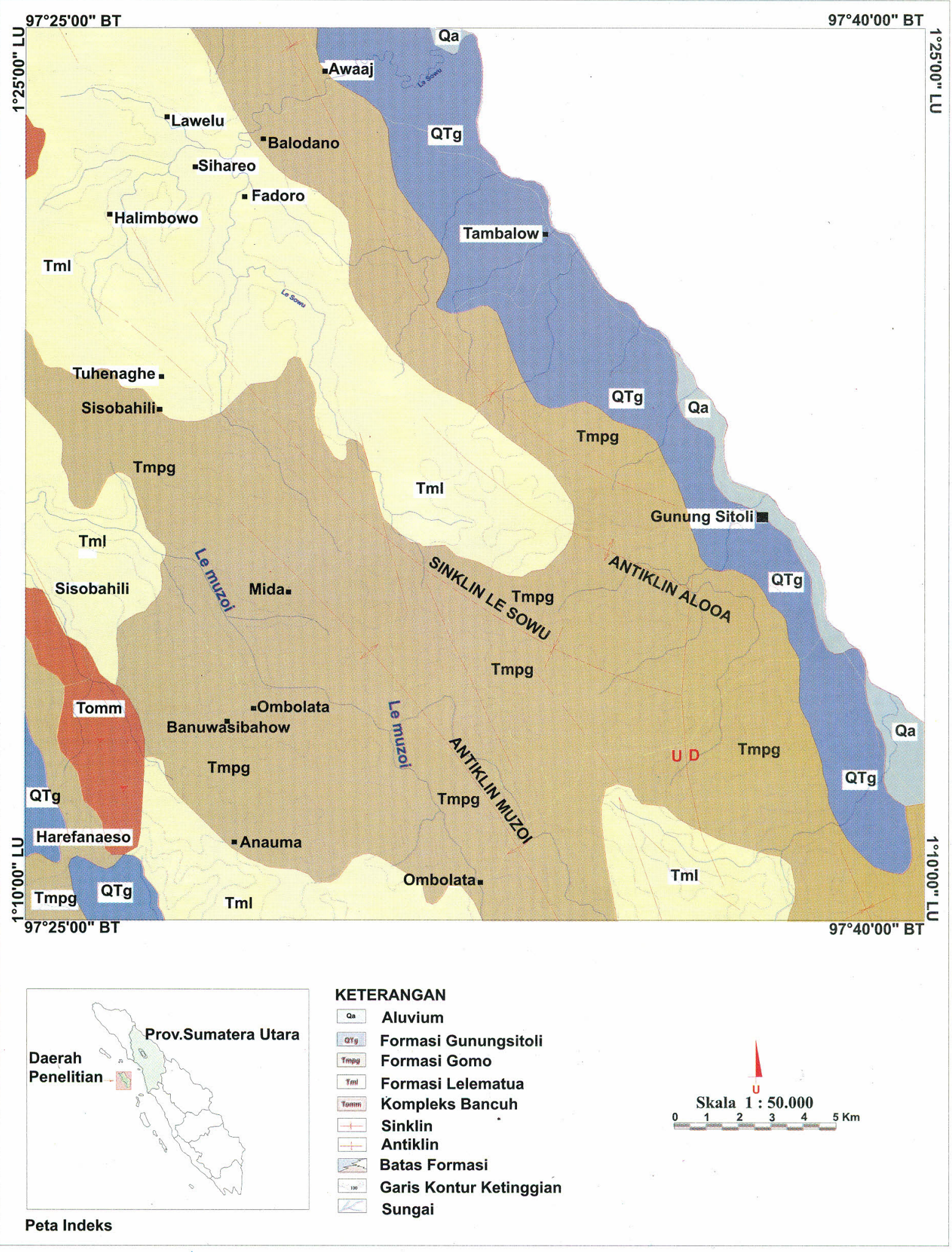

Gambar 2. Peta Geologi Daerah Kajian (Djamal B., dkk, 1994) 


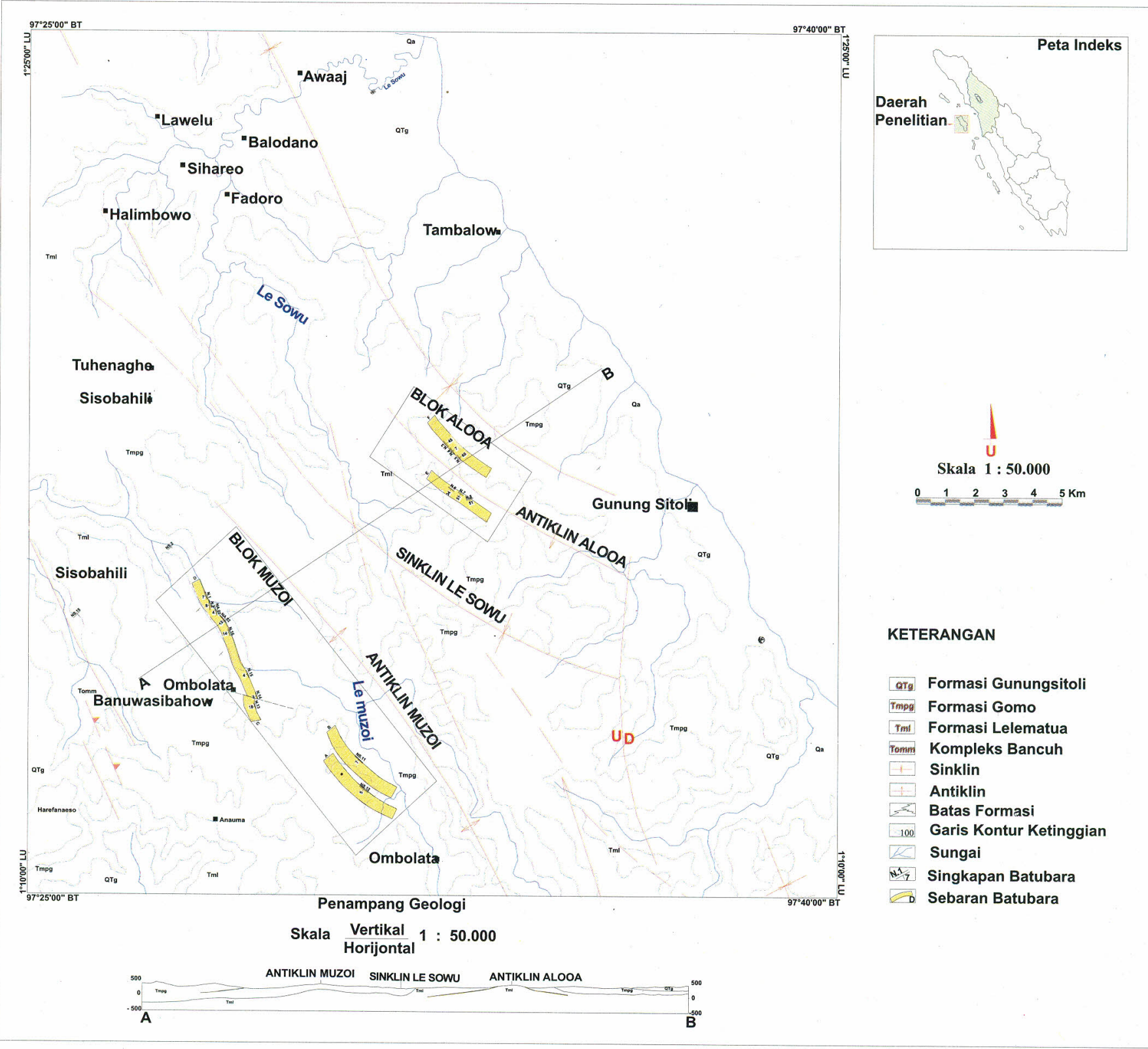

Gambar 3. Peta Sebaran Batubara Daerah Kajian (Modifikasi dari Djamal B.,dkk., 1994). 


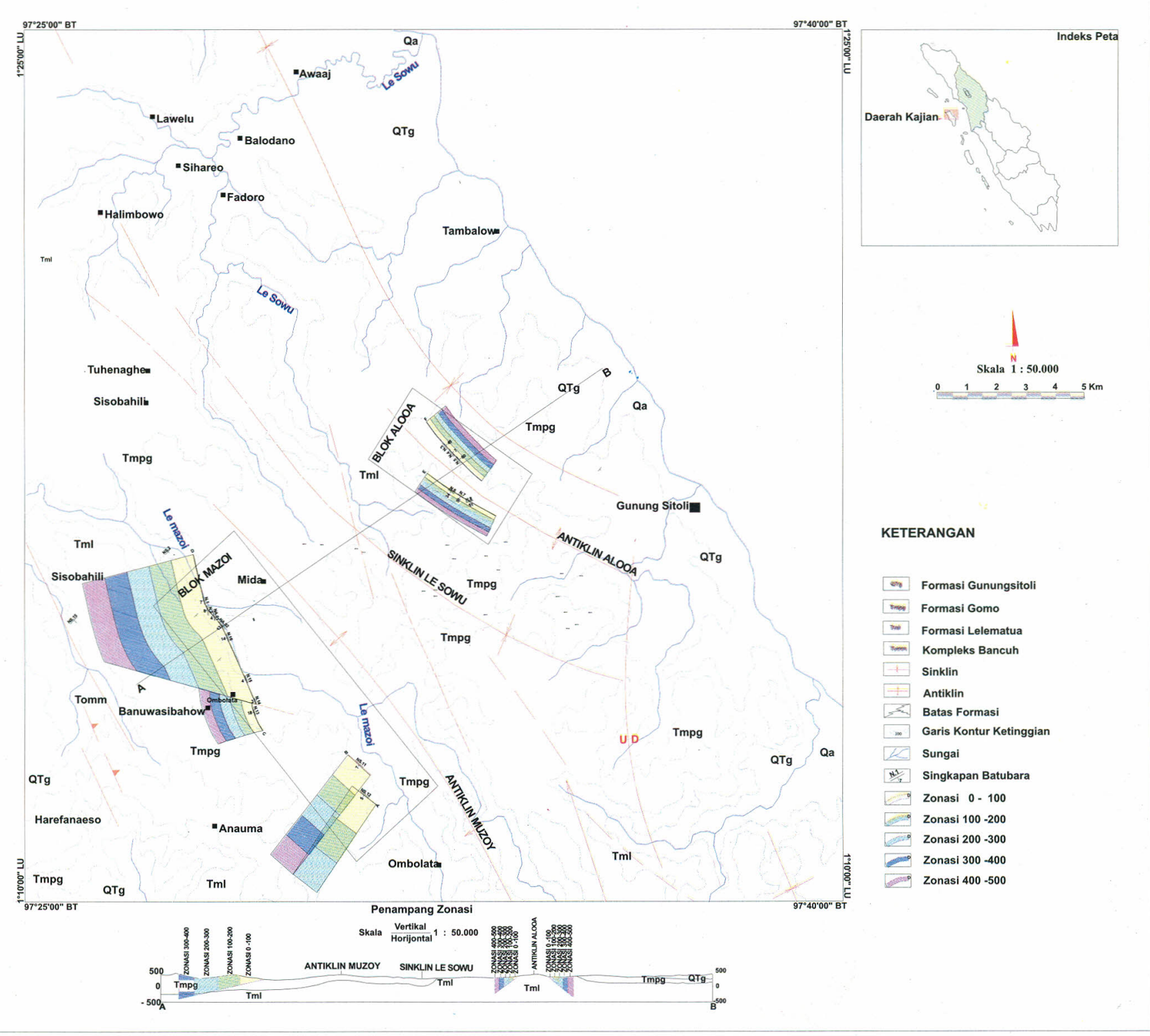

Gambar 4. Peta Zonasi Sebaran Batubara Daerah Kajian (Modifikasi dari Djamal B.,dkk., 1994) 


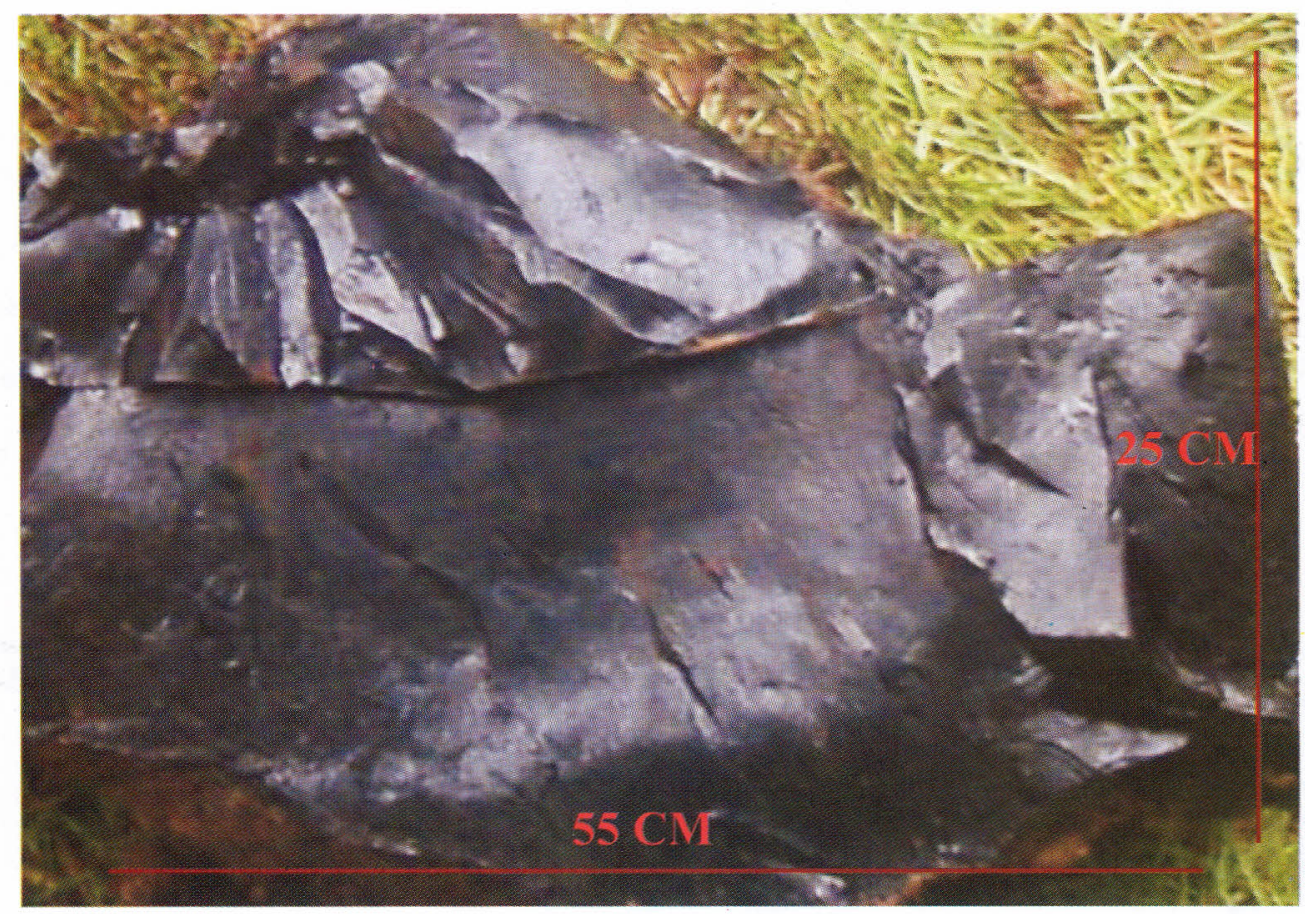

Foto 1. Kenampakan Singkapan Batubara Formasi Lelematua (Robert L.Tobing, dkk., 2006)

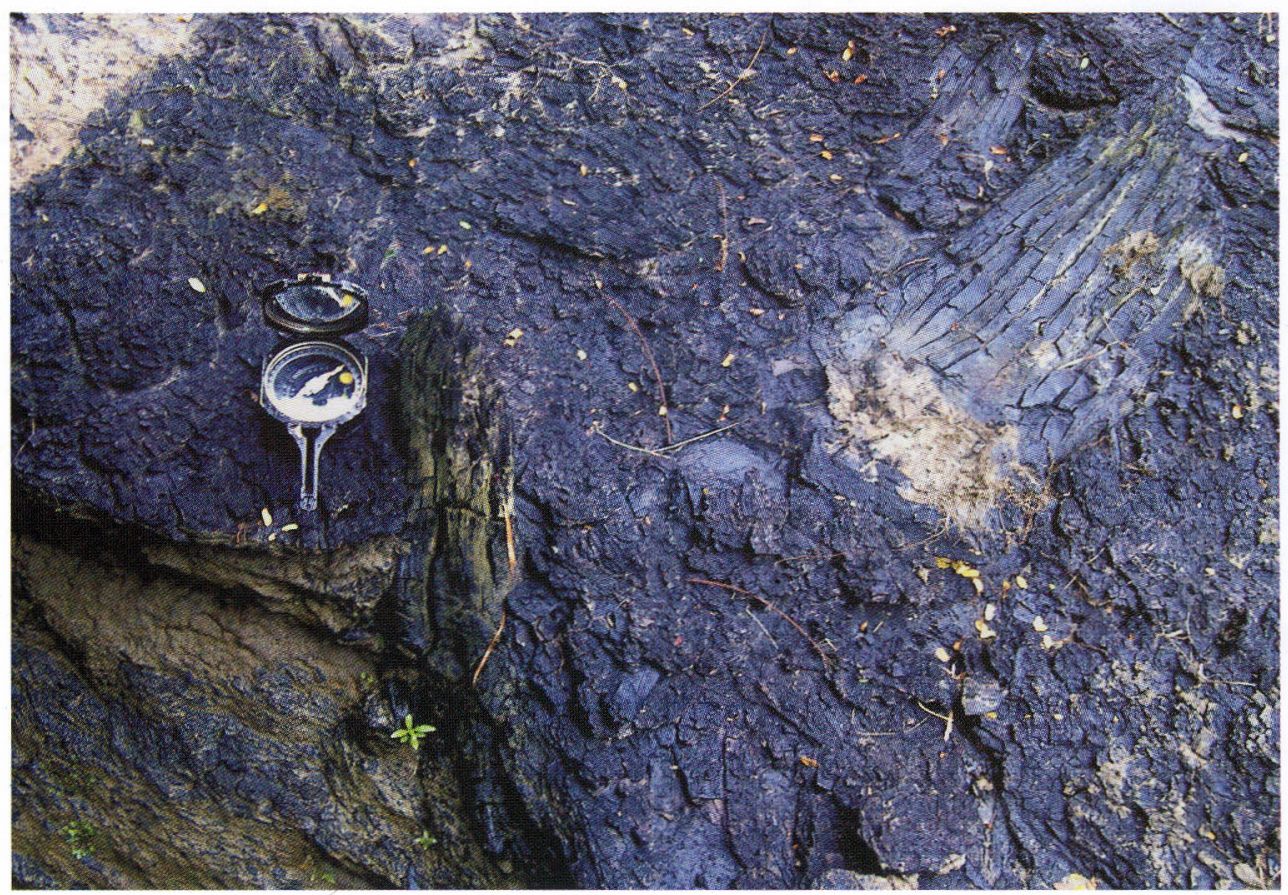

Foto 2. Kenampakan Singkapan Batubara Formasi Gomo (Robert L.Tobing, dkk.,2006). 